\title{
Effect on Microbial Population, Quality Parameters and Green Fodder Yield of Leguminous Crops under Bt Cotton Intercropping System
}

\author{
M. Daisy*, K. Rajendran and M. Mohamed Amanullah \\ Department of Agronomy, Tamil Nadu Agricultural University, \\ Coimbatore-3, Tamil Nadu, India \\ *Corresponding author
}

\begin{tabular}{|c|}
\hline Keywords \\
\hline $\begin{array}{l}\text { Annual legume } \\
\text { fodder, Quality } \\
\text { character, Root } \\
\text { nodules, Crude } \\
\text { protein, Crude fibre, } \\
\text { Total ash }\end{array}$ \\
\hline Article Info \\
\hline $\begin{array}{l}\text { Accepted: } \\
\text { 04 December } 2017 \\
\text { Available Online: } \\
\text { 10 January } 2018\end{array}$ \\
\hline
\end{tabular}

\section{A B S T R A C T}

Field experiments were conducted at Krishi Vigyan Kendra, Veterinary College and Research Institute, Namakkal during winter irrigated season of 2015- 2016 and 2016-2017 to study the different fertilizer levels in $B t$ cotton based annual legume fodder intercropping systems. The treatments comprised of intercropping systems in the main plot $\left(\mathrm{C}_{1}-\mathrm{Bt}\right.$ cotton alone; $\mathrm{C}_{2^{-}}$Bt cotton + fodder cowpea; $\mathrm{C}_{3}-\mathrm{Bt}$ cotton + horse gram; $\mathrm{C}_{4^{-}} \mathrm{Bt}$ cotton + moth bean; $\mathrm{C}_{5^{-}}$ $B t$ cotton + pillipesera) and different fertilizer levels in sub plot $\left(\mathrm{F}_{1}-100 \% \mathrm{RDF} ; \mathrm{F}_{2}-125 \%\right.$ $\left.\mathrm{RDF} ; \mathrm{F}_{3}-150 \% \mathrm{RDF}\right)$. The experiments were laid out in split plot design with three replications. Among the different intercrops studied, fodder cowpea recorded significantly higher growth attributes like plant height, LAI, DMP and CGR and green fodder yield as compared to horse gram, moth bean and pillipesera. Among three different fertilizer levels, significantly higher growth characters and green fodder yield were obtained by application of $150 \%$ RDF $\left(\mathrm{F}_{3}\right)$ followed by $125 \%$ RDF $\left(\mathrm{F}_{2}\right)$. Bt cotton + mothbean $\left(\mathrm{C}_{4}\right)$ had harvested higher solar energy at all the stages of crop growth than other intercropping system. $B t$ cotton + fodder cowpea $(\mathrm{C} 2)$ recorded higher number of root nodules, compared to other intercropping systems which recorded at 55 DAS during both the years. Application of $150 \%$ RDF intercepted more solar radiation followed by $125 \%$ RDF during important growth stages of the crop. Quality characters of green fodders viz., crude protein, crude fibre ether extract and total ash were not significantly influenced by the intercropping system and different fertilizer levels during both the years. Higher crude protein (5.67 and 4.65 per cent) and total ash content (4.98 and 4.61 per cent) in green fodder was recorded in mothbean $\left(\mathrm{C}_{4}\right)$ during both the years. However, higher crude fibre (7.26 and 6.55 per cent) content was noted in horse gram $\left(\mathrm{C}_{3}\right)$ and fat content of 0.88 and 0.81 per cent was observed in fodder cowpea $\left(\mathrm{C}_{2}\right)$ during both the years.

\section{Introduction}

Cotton enjoys a predominant position among all cash crops and called as fame name "king of fibres" and "white gold". Cotton is grown in more than 80 countries of China, India,
USA, Pakistan, Turkey, Brazil, Turkmenistan, Greece, Australia, Uzbekistan, Argentina and Egypt are major cotton producing countries in the world. India ranks first in area and second in total production in the world. Besides, India is a second largest consumer of raw cotton. 
Cotton cultivation in the world occupied 33.6 $\mathrm{m}$ ha in 2007-08. During 2007-08, cotton was grown on $9.4 \mathrm{~m}$ ha, of which the area under $\mathrm{Bt}$ cotton was $6.3 \mathrm{~m}$ ha with a productivity of 560 $\mathrm{kg}$ lint ha ${ }^{-1}$. Intercropping cotton (Gossypium hirsutum L.) is one of the ways to improve food security and soil fertility whilst generating cash income of the rural poor.

In this aspect, intercropping of short duration legumes in cotton has an positive effect on cotton performance but an additional yield of legume makes the system more profitable. The most important constraint in productivity of cotton legume intercropping systems is poor management. With legume as intercrop, there is good scope for providing nitrogen through its root nodules after the legume crop harvested.

Legumes play a vital role in contributing to food security, income generation and maintenance of environment for small-scale farmers. Legume intercrops are included in cropping system due to their ability to reduce soil erosion, improving land productivity through soil amelioration, suppress weeds and fix nitrogen.

Biological nitrogen fixation in legumes is a complementary effect which facilitates maintaining soil fertility. Carry-over of nitrogen from BNF through roots and stover, can supply the $\mathrm{N}$ demand of subsequent nonnitrogen fixing crops (van Kessel and Hartley 2000). BNF is an important process in cropping systems for replenishing $\mathrm{N}$, which is often the most limiting growth factor in tropical soils (Jeranyama et al., 1998).

The percentage $\mathrm{N}$ fixation and the $\mathrm{N}$ contribution from leguminous crops are influenced by crop species other factors like temperature, soil type, drought and moisture availability (Jensen et al., 1997). Short duration legume forages are potential sources of nutrients during summer especially atmospheric nitrogen fixing. Cotton production also enhanced through intercropping with short duration leguminous fodder crops due to their complementary effect.

\section{Materials and Methods}

\section{Site, climate and weather}

The field experiments were conducted in field No.362, Krishi Vigyan Kendra farm, Veterinary College and Research Institute Campus, Namakkal, during winter irrigated season (July-August) of 2015-16 and 2016-17 which is situated in the north western agro climatic zone of Tamil Nadu. The experimental field is located at $11^{\circ} 15^{\prime} \mathrm{N}$ latitude, $78^{\circ} 16^{\prime} \mathrm{E}$ longitude and an altitude of $218 \mathrm{~m}$ above mean sea level. During 2015-16, the crop received $544 \mathrm{~mm}$ of rainfall in 17 rainy days. The mean maximum and minimum temperature recorded were $33.17^{\circ} \mathrm{C}$ and $22.70^{\circ} \mathrm{C}$, respectively. During 2016-17, the crop received $140 \mathrm{~mm}$ of rainfall in 17 rainy days. The mean maximum and minimum temperature recorded were $34.37^{\circ} \mathrm{C}$ and $22.91^{\circ} \mathrm{C}$.

\section{Soil characteristics}

Soil samples from experimental site were collected randomly from six different sites. Soil was dug for $30 \mathrm{~cm}$ depth by using spade; around one kilogram of soil samples was collected (quartering method) and shade dried for 2-3 days. Collected soil samples were powdered well, sieved and finally used for analysis.

Estimation of initial soil $\mathrm{pH}, \mathrm{EC}$, major nutrients viz., nitrogen, phosphorus and potassium, organic carbon and micronutrients viz., sodium, magnesium, calcium was carried out. Result of soil N, P and K were expressed 
in $\mathrm{kg} \mathrm{ha}{ }^{-1}$. The results of physico-chemical properties of soil revealed that the soil was sandy clay loam in texture (Typic Ustropept). The nutrient status of soil at the initial stage of experiment field was low in available nitrogen $\left(251.5 \mathrm{~kg} \mathrm{ha}^{-1}\right)$, low in phosphorus $\left(9.7 \mathrm{~kg} \mathrm{ha}^{-}\right.$ $\left.{ }^{1}\right)$ and low in available potassium $\left(79.0 \mathrm{~kg} \mathrm{ha}^{-}\right.$ $\left.{ }^{1}\right)$. The recommended dose of 120:60:60 kg NPK ha ${ }^{-1}$ (100\% RDF) was applied uniformly to the sub plot as a treatment $\left(\mathrm{F}_{1}\right)$ in the form of inorganic fertilizers such as urea $(46 \%$ of $\mathrm{N})$, single super phosphate $\left(16 \%\right.$ of $\left.\mathrm{P}_{2} \mathrm{O}_{5}\right)$ and muriate of potash $\left(60 \%\right.$ of $\left.\mathrm{K}_{2} \mathrm{O}\right)$ to supply of nitrogen, phosphorous and potassium, respectively.

The viable, good quality, bold and delinted seeds were treated with Thiram $2 \mathrm{~g} \mathrm{~kg}^{-1}$ of seeds after the fungicide treated seeds are treated with Trichoderma viride @ $4 \mathrm{~g} \mathrm{~kg}^{-1}$ of seed for better germination and better stand in the field. Germination of cotton seeds was noted from third day after sowing and continued upto seven DAS. Gap filling was done on seventh day after sowing. The economic part of cotton i.e. cotton kapas was picked in the ten days interval and the yield recorded at each picking. Totally four picking were done and carried out in the morning hours upto 11 a.m. Care was taken to prevent the leaves and bracts do not stick with kapas so as to reduce the contaminants while picking the cotton kapas from the bolls. The kapas were shade dried and weighed and the yield was recorded. Intercrops were harvested above from the ground level as green fodder at 55 days after sowing. Intercrops of fodder cowpea, horsegram, mothbean and pillipesera were harvested separately from its individual plot and weighed and green fodder yield was recorded as $\mathrm{kg} \mathrm{ha}^{-1}$. Data on soil nutrient uptake and available nutrient status after harvest was subjected to statistical analysis. Quality parameters of intercrop was estimated in the laboratory as per the procedure and statistically analysed.

\section{Results and Discussion}

\section{Quality parameters of intercrops}

The following effect was noted under intercropping system and fertilizer levels on quality parameters of green fodder at harvest stage during both the years of the study. Among the intercrops moth bean (C4) recorded higher crude protein (22.33 and 22.68 per cent) (Table 1).

The total ash content was more in moth bean (4.98 and 4.61 per cent during both the years of study) under $B t$ cotton+ moth bean (C4) intercropping system when compared to other intercrops and the lower total ash value (2.99 and 2.68 per cent) was observed under fodder cowpea (C2) when intercropped with $B t$ cotton. Among the various fodder intercrops horse gram (C3) recorded maximum $\mathrm{CF}$ content (7.26 per cent and 6.65 per cent in first and second years) at harvest stage (55 DAS) during both the years when compared to other intercrops.

The estimated fat value of green fodder was more ( 0.88 and 0.81 per cent) in fodder cowpea (C2) when compared to other legume fodder harvested at 55 DAS during both years, respectively and the lower value (0.62 and 0.61 per cent) was observed under pillipesera (C5) when intercropped with Bt cotton.

\section{Green fodder yield of leguminous crops}

Under $B t$ cotton + legume fodder intercropping system, fodder cowpea with application of $150 \%$ RDF $\left(\mathrm{C}_{2} \mathrm{~F}_{3}\right)$ produced higher green fodder yield $\left(17407 \mathrm{~kg} \mathrm{ha}^{-1}\right)$ at 55 DAS during first year, and it was recorded as $14431 \mathrm{~kg}$ ha-1 during second year study. It was followed by $B t$ cotton + fodder cowpea with $125 \%$ RDF $\left(\mathrm{C}_{2} \mathrm{~F}_{2}\right)$ application with values of 12953 and $12544 \mathrm{~kg}$ ha-1 during first and second year, respectively. 
Table.1 Effect of crude protein, crude fibre, ether extract and total ash (\%) content legume fodder intercropping systems on fresh weight basis as influenced by fertilizer levels of $B t$ cotton

\begin{tabular}{|c|c|c|c|c|c|c|c|c|}
\hline \multirow[t]{2}{*}{ Treatments } & \multicolumn{4}{|c|}{ 2015-2016 } & \multicolumn{4}{|c|}{ 2016-2017 } \\
\hline & $\begin{array}{c}\text { Crude } \\
\text { protein } \\
(\%)\end{array}$ & $\begin{array}{c}\text { Crude } \\
\text { fibre } \\
(\%)\end{array}$ & $\begin{array}{c}\text { Fat } \\
\text { Content } \\
(\%)\end{array}$ & $\begin{array}{c}\text { Total } \\
\text { ash } \\
(\%)\end{array}$ & $\begin{array}{c}\text { Crude } \\
\text { protein } \\
(\%)\end{array}$ & $\begin{array}{c}\text { Crude } \\
\text { fibre } \\
(\%)\end{array}$ & $\begin{array}{c}\text { Fat } \\
\text { Content } \\
(\%)\end{array}$ & $\begin{array}{c}\text { Total } \\
\text { ash } \\
(\%)\end{array}$ \\
\hline \multicolumn{9}{|c|}{ Fodder intercropping systems } \\
\hline $\mathrm{C}_{1}$ & - & - & - & - & - & - & - & - \\
\hline$\overline{\mathrm{C}_{2}}$ & 20.98 & 4.02 & 0.88 & 2.99 & 20.22 & 3.68 & 0.81 & 2.68 \\
\hline$\overline{\mathrm{C}_{3}}$ & 20.66 & 7.26 & 0.84 & 4.77 & 21.44 & 6.65 & 0.80 & 3.92 \\
\hline$\overline{\mathrm{C}_{4}}$ & 22.33 & 6.13 & 0.77 & 4.98 & 22.68 & 5.82 & 0.71 & 4.61 \\
\hline$\overline{\mathrm{C}_{5}}$ & 19.36 & 3.07 & 0.62 & 3.32 & 18.25 & 2.83 & 0.61 & 3.18 \\
\hline SEd & 0.44 & 0.11 & 0.02 & 0.09 & 0.43 & 0.11 & 0.02 & 0.08 \\
\hline $\mathrm{CD}(\mathrm{P}=0.05)$ & 1.06 & 0.26 & 0.04 & 0.21 & 1.02 & 0.24 & 0.03 & 0.19 \\
\hline \multicolumn{9}{|c|}{ Fertilizer levels } \\
\hline $\mathbf{F}_{1}$ & 20.17 & 4.73 & 0.70 & 3.63 & 19.60 & 4.26 & 0.67 & 3.35 \\
\hline $\mathbf{F}_{2}$ & 20.76 & 5.04 & 0.76 & 4.00 & 20.08 & 4.89 & 0.72 & 3.69 \\
\hline $\mathbf{F}_{3}$ & 21.57 & 5.61 & 0.88 & 4.42 & 22.27 & 5.09 & 0.81 & 3.57 \\
\hline SEd & 0.41 & 0.10 & 0.01 & 0.08 & 0.38 & 0.09 & 0.01 & 0.08 \\
\hline $\mathrm{CD}(\mathrm{P}=0.05)$ & 0.90 & 0.22 & 0.03 & 0.17 & 0.83 & 0.20 & 0.02 & 0.16 \\
\hline
\end{tabular}

Table.2 Effect on green fodder yield $\left(\mathrm{kg} \mathrm{ha}^{-1}\right)$ of legume fodder intercrops as influenced by different fertilizer levels of Bt cotton

\section{Fodder intercropping systems}

\begin{tabular}{|c|c|c|c|c|c|}
\hline $\begin{array}{c}\text { Fertilizer } \\
\text { levels }\end{array}$ & $\begin{array}{c}\text { Fodder } \\
\text { cowpea }\left(\mathbf{C}_{\mathbf{2}}\right)\end{array}$ & $\begin{array}{c}\text { Horse } \\
\text { gram }\left(\mathbf{C}_{\mathbf{3}}\right)\end{array}$ & $\begin{array}{c}\text { Moth } \\
\text { bean }\left(\mathbf{C}_{\mathbf{4}}\right)\end{array}$ & $\begin{array}{c}\text { Pillipesera } \\
\left(\mathbf{C}_{\mathbf{5}}\right)\end{array}$ & Mean \\
\hline $\mathrm{F}_{1}$ & 12690 & 3627 & 9228 & 2788 & $\mathbf{7 0 8 3}$ \\
\hline $\mathrm{F}_{2}$ & 12953 & 3899 & 9475 & 3041 & $\mathbf{7 3 9 2}$ \\
\hline $\mathrm{F}_{3}$ & 17407 & 4439 & 10041 & 3066 & $\mathbf{8 7 3 8}$ \\
\hline Mean & $\mathbf{1 4 3 5 0}$ & $\mathbf{3 9 8 8}$ & $\mathbf{9 5 8 1}$ & $\mathbf{2 9 6 5}$ & \\
\hline Fertilizer & & & $\mathbf{2 0 1 6 - 2 0 1 7}$ & & \\
\hline levels & Fodder & Horse & Moth & Pillipesera & Mean \\
\hline & cowpea $\left(\mathbf{C}_{\mathbf{2}}\right)$ & gram $\left(\mathbf{C}_{\mathbf{3}}\right)$ & bean $\left(\mathbf{C}_{\mathbf{4}}\right)$ & $\left(\mathbf{C}_{\mathbf{5}}\right)$ & \\
\hline $\left.\mathrm{F}_{1}\right)$ & 9865 & 3121 & 5631 & 1112 & $\mathbf{4 9 3 2}$ \\
\hline $\mathrm{F}_{2}$ & 12544 & 3874 & 7292 & 1478 & $\mathbf{6 2 9 7}$ \\
\hline $\mathrm{F}_{3}$ & 14431 & 4662 & 10010 & 2720 & $\mathbf{7 9 5 6}$ \\
\hline Mean & $\mathbf{1 2 2 8 0}$ & $\mathbf{3 8 8 6}$ & $\mathbf{7 6 4 4}$ & $\mathbf{1 7 7 0}$ & \\
\hline
\end{tabular}


Table.3 Effect of legume fodder intercropping systems and fertilizer levels on bacteria, CFU (x10 $\mathrm{g}^{-1}$ dry soil), fungi and actinomycetes CFU $\left(10^{4}\right)$ in soil

\begin{tabular}{|c|c|c|c|c|c|c|}
\hline \multirow[t]{3}{*}{ Treatments } & \multicolumn{6}{|c|}{$2015-2016$} \\
\hline & \multicolumn{2}{|c|}{ Bacteria } & \multicolumn{2}{|c|}{ Fungi } & \multicolumn{2}{|c|}{ Actinomycetes } \\
\hline & 55 DAS & 120 DAS & 55 DAS & 120 DAS & 55 DAS & 120 DAS \\
\hline \multicolumn{7}{|c|}{ Fodder Intercropping systems } \\
\hline$\overline{C_{1}}$ & 83.15 & 176.5 & 36.61 & 44.61 & 31.61 & 28.25 \\
\hline $\mathrm{C}_{2}$ & 90.53 & 188.5 & 34.81 & 44.18 & 30.81 & 30.13 \\
\hline $\mathrm{C}_{3}$ & 68.33 & 164.2 & 33.00 & 39.00 & 29.66 & 28.10 \\
\hline $\mathrm{C}_{4}$ & 75.24 & 168.6 & 36.82 & 44.85 & 36.39 & 34.47 \\
\hline $\mathrm{C}_{5}$ & 65.64 & 148.9 & 35.16 & 40.36 & 31.22 & 31.17 \\
\hline SEd & 2.15 & 4.78 & 1.07 & 1.31 & 1.01 & 0.95 \\
\hline $\mathrm{CD}(\mathrm{P}=0.05)$ & 4.96 & 11.02 & 2.47 & 3.02 & 2.34 & 2.19 \\
\hline \multicolumn{7}{|l|}{ Fertilizer levels } \\
\hline $\mathbf{F}_{1}$ & 73.21 & 149.4 & 31.23 & 39.21 & 29.37 & 28.40 \\
\hline $\mathbf{F}_{2}$ & 78.29 & 170.9 & 35.76 & 42.50 & 31.80 & 30.27 \\
\hline $\mathrm{F}_{3}$ & 78.23 & 187.8 & 38.84 & 46.08 & 34.64 & 32.60 \\
\hline SEd & 1.21 & 2.62 & 0.57 & 0.71 & 0.54 & 0.52 \\
\hline $\mathrm{CD}(\mathrm{P}=0.05)$ & 2.53 & 5.47 & 1.18 & 1.48 & 1.12 & 1.07 \\
\hline Interaction & NS & NS & NS & NS & NS & NS \\
\hline
\end{tabular}

The lower green fodder yield was produced under the treatment of $B t$ cotton + fodder cowpea along with the application of $100 \%$ RDF (C1F1) with $12690 \mathrm{~kg} \mathrm{ha}^{-1}$ during first year and $9865 \mathrm{~kg} \mathrm{ha}^{-1}$ during second year at 55 DAS.

Among the intercrops fodder cowpea significantly recorded higher green fodder yield as compared to other intercrops viz., horse gram, moth bean and pillipesera and pure stand of cotton. Similarly among the three fertilizer management practices, application of $150 \%$ RDF produced the higher growth characters and yield of intercrops then 100 per cent RDF (Table 2). It might be due to fast growing habit and earlier establishment than other fodders.

The yield reduction in $B t$ cotton pure stand over intercropped moth bean was 8.5 to 10.5 per cent as against 14.73 to 18.51 per cent in cotton intercropped with pillipesera. But the yield reduction of $B t$ cotton intercropped with fodder cowpea was 9.80 to 10.43 per cent over sole cotton. Lower yield might be due to increased competition between main crop and intercrop for long duration which leads to lesser production of sympodial branches, finally lesser boll production (Khargkharate et al., 2014). But these yield reduction was compensated by green fodder yield of fodder cowpea. The increase in seed cotton yield equivalent was due to higher additional fodder yield from fodder cowpea intercrop. This finding is in agreement with Chellaiah and Gopalaswamy (2000).

\section{Effect on soil microbial population}

The microbial population of bacteria, fungus and actinomycetes were recorded at 55 and 120 DAS. In general, the treatment Bt cotton + fodder cowpea $\left(\mathrm{C}_{2}\right)$ recorded higher bacterial population. $B t$ cotton + fodder cowpea $\left(\mathrm{C}_{2}\right)$ recorded significantly higher bacterial population of 90.53 and $188.5 \mathrm{CFU}\left(\times 10^{6} \mathrm{~g}^{-1}\right.$ of dry soil) at 55 and 120 DAS during 2015-2016 respectively, and the treatment $B t$ cotton + moth bean $\left(\mathrm{C}_{4}\right)$ recorded higher fungus and actinomycetes population as compared to the $\mathrm{Bt}$ cotton pure stand and other intercropping 
systems. The population of microbes such as bacteria, fungi and actinomycetes was significantly superior under intercropped systems than sole crop of cotton (Table 3).

This might be due to a greater root biomass of intercropping systems than that of sole crop. Becker and Ladha (1995) and Peoples et al., (1995) reported that the incorporation of legume stubbles under intercropping systems contributed large amount of nitrogen and organic matter to the soil and also favoured for the better proliferation of the soil microorganisms.

The experimental results enlightened that there was marked variations on the productivity of $B t$ cotton due to adoption of different annual legume fodder intercropping systems with different levels of fertilizers. Considering the biological and economical performance of cotton intercropping system, the conclusion generated from these experiments for recommendation in Tamil Nadu is, Bt cotton + mothbean with application of $150 \%$ RDF is an ideal combination.

This treatment had registered higher cotton yield and B: $\mathrm{C}$ ratio. Further it can be concluded from the above study $B t$ cotton + fodder cowpea combination produced more green fodder yield and realized higher net returns than other intercropping systems might be yield reduction in seed cotton was compensated by good value of green fodder.

\section{References}

Becker, M. and J. K. Ladha. 1995. Green manure technology. Potential usage and limitations. Plant and Soil. 174.

Chellaiah, N. and N. Gopalaswamy. 2000. Effect of intercropping and foliar nutrition on the productivity of summer irrigated cotton. Madras Agric, J., 87(46): 267-270.

Jensen ES, Høgh-Jensen H, Jørgensen FV, Schjørring JK, Vinther FP 1997. Management of biological nitrogen fixation in grass/clover leys. In: Kristensen NH, Høgh- Jensen H (eds) New research in organic agriculture. IFOAM, Tholey-Theley. Pp. 89-96.

Jeranyama P, Hesterman OB, Waddington SR 1998. The impact of legumes relay intercropped into maize at Domboshava, Zimbabwe. In: Waddington SR, Murwira HK, Kumwenda JDT, Hikwa D, Tagwira F (eds) Soil fertility research for maizebased farming systems in Malawi and Zimbabwe. Proceedings of the Soil Fertility Network results and planning workshop, 7-11 July 1997, Mutare, Zimbabwe. Soil Fert Net and CIMMYTZimbabwe, Harare, Zimbabwe, pp. 31-34 Khargkharate, V. K., G. L. Kadam, A. D. Pandagale, V. B. Awasarmal and S. S. Rathod. 2014. Studies on kharif legume intercropping with $B t$ cotton under rainfed conditions. J. Cotton Res. Dev., 28(2): 243-246.

Peoples, M.B., D.F. Herridge and J.K. Ladha. 1995. Biological nitrogen fixation an efficient source of nitrogen foe sustainable agriculture. Plant and Soil, Pp. 174.

Van Kessel C, Hartley H. 2000. Agricultural management of grain legumes: has it led to an increase in nitrogen fixation? Field Crops Res 65:165-181.

\section{How to cite this article:}

Daisy, M., K. Rajendran and Mohamed Amanullah, M. 2018. Effect on Microbial Population, Quality Parameters and Green Fodder Yield of Leguminous Crops under Bt Cotton Intercropping System. Int.J.Curr.Microbiol.App.Sci. 7(01): 332-337.

doi: https://doi.org/10.20546/ijcmas.2018.701.037 